\title{
Characterization of Variability, Genetic Divergence and Character Association in Wheat Germplasm of SWRS in Respect of Nutrition and Yield Traits
}

\author{
Ishan Ahmed ${ }^{1}$, Jitendra Kumar ${ }^{1}$, Neha Goel ${ }^{1}$, Vinod Kumar Mishra ${ }^{2}$ and \\ Pradeep Kumar Sharma ${ }^{*}$
}

${ }^{1}$ Department of Genetics and Plant Breeding, Ch. Charan Singh University, Meerut, India

${ }^{2}$ Banaras Hindu University Varanasi, India

*Corresponding author

\begin{tabular}{|l|}
\hline K e y w o r d s \\
Bread wheat (Triticum \\
aestivum L.), ANOVA, \\
Correlation coefficient, \\
Cluster analysis
\end{tabular}

Keywords

Bread wheat (Triticum aestivum L.), ANOVA, Article Info

Accepted: Available Online: May 2018

\section{A B S T R A C T}

Genetic diversity and the association of the target traits with other traits are the foundation for any crop improvement programme. 308 genotypes of spring wheat reference set (SWRS) were evaluated in simple lattice during crop-season 2015-16 to study genetic diversity and, character association. Phenotypic data were recorded on 15 nutrients and grain yield traits. Analysis of variance revealed significant differences among all the genotypes. The estimates of $\mathrm{CV}$ indicated highest variability for agronomic traits like GWPS followed in descending order by GYPP, TNPP, TGW, GNPS and biological yield. For nutrient traits, the maximum variability was observed for $\mathrm{GZnC}$, followed in decreasing order by GBCC, GFeC and GPC. Correlation was calculated among all the 15 traits. Out of the total 105 paired combinations of all the 15 traits, only 72 combinations were significant (36 positive and 36 negative). The values of significant positive correlation varied from 0.11 (GPC-Fe) to 0.99 (DTH-DTA) and values of significant negative correlation ranged from-0.11 (TNPP-GYPP) to-0.724 (DTAGYPP) respectively. Genetic diversity analysis formed 12 groups and intra-cluster distance varied from 31.97 to 163.55 with the maximum distance was in cluster-II and the minimum distance was in cluster-X, indicated close relationships among the genotypes. The highest inter-cluster distance was exhibited between clusters I and II $\left(D^{2}=696.93\right)$, indicated a wider genetic divergence among the clusters. The lowest $D^{2}$ value was observed between clusters $X$ and XI $\left(D^{2}=44.47\right)$, indicated that these clusters were genetically close. Further we selected eight important clusters for different traits, out of which cluster III was important for GPC and GZnC, cluster V was for iron and cluster VI was for DTM, TGW and GBCC respectively, remaining five clusters were for remaining agronomic trait. Furthermore, we also selected 10 common genotypes with highest trait values for different traits, these genotypes may be further used for improvement of more than one traits with high trait value in wheat breeding programe. 


\section{Introduction}

Wheat is a major staple food crop in India as well as in the world for consumption and production (Wang et al., 2011). It is consumed by more than $40 \%$ of world population. The starchy endosperm of mature wheat grain consists of carbohydrates (simple starches) making $55-75 \%$ of the total dry grain weight and storage proteins making another 10-20\% (Gillies et al., 2012). The aleurone layer of the wheat grain is most important source of vitamins, micronutrients, minerals, phytochemicals and fibre in wheat grain, although it is also rich in proteins and lipids (Geisler-Lee and Gallie, 2005; Liu, 2011; Regvar et al., 2011).

Wheat bran is the valuable source of bioactive components due to its importance for human health. Wheat grains also contain healthcare micronutrients ( $\mathrm{Fe}, \mathrm{Zn}$ and $\beta$-carotenoid) as minor constituents. The deficiency of which is the major global challenge to human health. Over three billion people, including one third of the children in developing countries, suffer from micronutrient malnutrition/hidden hunger world-wide (Distelfeld et al., 2007). It is estimated that $>60 \%$ of the world population suffers from malnutrition due to $\mathrm{Fe}$ deficiency and $>30 \%$ due to $\mathrm{Zn}$ deficiency (White et al., 2009).

It is also reported that poor pregnancy outcome/impaired or stunted growth in children are caused due to $\mathrm{Zn}$ deficiency. Similarly, 190 million preschool-children and 19.1 million pregnant women around the world have a $\beta$-carotenoid concentration below the minimum required 0.70 micromoles/L (WHO, 2009).

The deficiency of these micronutrients causes many serious diseases like anaemia (due to $\mathrm{Fe}$ deficiency), night blindness and xerophthalmea, cardiovascular diseases and types of cancers and neurological disorders due to $\beta$-carotenoid (Colasuonno et al., 2017).

Grain protein content (GPC) is another important trait, which has an impact on the nutritional value of the grain and the technological property of the flour. Protein content and essential amino acids also affect the key body functions including development and maintenance of muscles. The deficiency of protein has also been reported to be responsible for protein-energy malnutrition (PEM) that is mainly observed in children. Around 161 million children worldwide are known to be affected by PEM (http://www.worldhunger.org/2015-worldhunger-and-poverty-facts-and-statistics/).

Several strategies have been suggested to overcome micronutrient malnutrition in human populations (Nguni et al., 2012). They comprise food fortification, dietary supplementation by use of complementary tablets. Other strategies are dietary diversification and micronutrient biofortification through plant breeding methods (Nguni et al., 2012). Biofortification through plant breeding (which is known as genetic improvement) has been identified to be potentially more sustainable and less expensive, since seeds could reach a larger number of people without necessarily changing consumer's behavior (OrtizMonasterio et al., 2007; Cakmak, 2008; Nguni et al., 2012).

In view of the above, there is a need to improve wheat grain for helthcare micronutrients, to alleviate hidden hunger in humans, especially in those below the poverty line (Welch and Graham, 2004; OrtizMonasterio et al., 2007). Therefore the present study, was undertaken to identify genetically diverse genotypes which can beused in plant breeding for improvement of micronutrient contents which maintaining the grain yield. 


\section{Materials and Methods}

\section{Study materials and phenotypic data}

The study material comprised 324 wheat genotypes of (SWRS) procured from CIMMYT, Mexico, was evaluated in a simple lattice design of $18 \times 18$ (with two replications) in crop-season 2015-16 at Research Farm, Department of Genetics and Plant Breeding, Ch. Charan Singh University, Meerut, Uttar Pradesh, India. Each genotype was raised in a plot of 3 rows of $1.5 \mathrm{~m}$ each with a row to row and plant to plant distance of $25 \mathrm{~cm}$ and $10 \mathrm{~cm}$ respectively.

Phenotypic data were recorded only on 308 genotypes (the data for 16 genotypes was missing) for the following fifteen traits: $(i)$ days to heading (DTH), (ii) days to anthesis (DTA), (iii) days to maturity (DTM), (iv) grain filling duration (GFD), (v) plant height (PH), (vi) tiller no. per plant (TNPP), (vii) grain no. per spike (GNPS), (viii) grain weight per spike (GWPS) in g, (ix) thousand grain weight (TGW) in $\mathrm{g},(x)$ biological yield (BY) in $\mathrm{g},(x i)$ grain yield per plot (GYPP) in $\mathrm{g}$, (xii) grain protein content (GPC) as per cent grain weight, (xiii) grain $\beta$-carotenoid content (GBCC) in $\mu \mathrm{g} / \mathrm{g}$, (xiv) grain iron content $(\mathrm{GFeC})$ in ppm and (xv) grain zinc content $(\mathrm{GZnC})$ in ppm. The FOSS (Infra-tech 1241) grain analyser was used to estimate the protein (\%) and $\beta$-carotenoid content $(\mu \mathrm{g} / \mathrm{g})$ of the grains. The $\mathrm{GZnC}$ and $\mathrm{GFeC}$ estimates (ppm) were determined using $\mathrm{X}$-ray Fluorescence (EDXRF spectrometer X-Supreme 8000 (Paltridge et al., 2012).

\section{Statistical analysis}

\section{Descriptive statistics}

The descriptive statistics including mean, range, standard error, coefficient of variation $(\mathrm{CV}$ as \%) and Pearson's correlation coefficients were calculated using SPSS 17.0 and analysis of variance (ANOVA) was carried out using SAS 9.2.

\section{Heritability}

Heritability $\left(h^{2}\right)$ in broad sense for each character was calculated according to the formula suggested by Allard et al., (1960)

$$
\mathrm{h}^{2}={ }^{\frac{\sigma_{g}^{2}}{\sigma_{p}^{2}}}
$$

\section{Genetic divergence}

Genetic divergence of all genotypes was estimated through Mahalanobis $\mathrm{D}^{2}$ and cluster analysis using Wards method respectively (Mahalanobis, 1936; Ward et al., 1963).

\section{Results and Discussion}

Analysis of variance, descriptive statistics and heritability

The result of analysis of variance (ANOVA) presented in Table 1, reveals that the mean squares of all the traits excepting DTH and DTA were highly significant which indicates the presence of variability among the genotypes used in present study. The estimates of descriptive statistics, including mean, range, standard deviation (SD), standard error (SE) coefficient of variance (CV) and heritability are presented in Table 2 .

The wide range in the minimum and maximum values of genotypic means was observed for different traits such as GPC $(11.18-17.93 \%)$, GBCC $(2.65-6.90 \mathrm{mg} / \mathrm{kg})$, GFeC (29.20-59.50 ppm), GZnC (11.70-39.05 ppm), DTH (72- 129 days), DTA (80-132 days), DTM (115-160 days), GFD (24-47 days), PH (60.45 -149.03 cm), GNPS (17.0061.50), GWPS (0.45-2.74 g), TGW (15.25$53.19 \mathrm{~g})$, BY (387.50-1750.00 g), and GYPP 
(100.00-562.50 g), which indicated presence of phenotypic and genotypic variability for all the traits, especially the micronutrient traits in SWRS genotypes (Table 2). In addition, the estimates of descriptive statistics also support the results of ANOVA which indicated that the sufficient variability is present for all the traits in the genotypes used in present study.

The estimates presented in Table 2 indicated that among the grain yield and its related traits, the highest variability was observed for GWPS followed in descending order by GYPP, TNPP, TGW, GNPS and BY. For rest of the yield related traits, the variability was moderate to low. Previous studies are supporting the above research findings (Bergale et al., 2001; Dwivedi et al., 2002; Asif et al., 2004; Welchet al., 2005; OrtizMonasterio et al., 2007; Zhao et al., 2009; Tripathi et al., 2011). For nutrient traits, the maximum variability was observed for GZnC $(\mathrm{CV}=16.53$, range $=11.70-39.05 \mathrm{ppm})$, followed in decreasing order by GBCC $(\mathrm{CV}=14.34$, range $=2.65-6.90 \mathrm{mg} / \mathrm{kg}), \mathrm{GFeC}$ $(\mathrm{CV}=12.27$, range $=9.20-59.50)$ and $\mathrm{GPC}$ $(\mathrm{CV}=9.20$, range $=11.18-1793)$. The previous studies also suggest the similar pattern of variability for these nutrient traits (Cakmak et al., 2004; Tiwari et al., 2016; Velu et al., 2016; Bityutskii et al., 2017). Estimates of broad sense heritability $\left(\mathrm{h}^{2}\right)$ of nutritional traits ranged from $64.07 \%(\mathrm{GFeC})$ to 88.96 (GPC) and that for yield traits ranged from $96.04 \%$ (GFD) to $99.68 \%$ (PH), Heritability is the percentage of phenotypic variance that is attributed to genetic variance. In the present study heritability, was high for all studied traits, high heritability indicates that the environmental influence is minimal on traits. Thus, above results suggested that, this germplasm may be useful for wheat breeding programs, especially targeted for improvement of nutrition traits (GPC, GBCC, GFeC and $\mathrm{GZnC}$ ) to alleviate micronutrients malnutrition.

\section{Correlation coefficient analysis}

The estimation of correlation coefficient presented in Table 3 showed that, out of the total 105 paired combinations of all the traits, only 36 positive and 36 negative significant correlations were identified for all the traits. The values of significant positive correlation varied from 0.11 (GPC-GFeC) to 0.99 (DTHDTA) and values of significant negative correlation ranged from -- 0.11 (TNPP-GYPP) to -0.724 (DTA-GYPP).

While considering the correlations of interest in present study, i.e. yield and yield component traits vs. nutrients traits, significant positive correlation were observed between DTA and GPC $(r=0.61)$, DTA and GZnC ( $r=0.60)$, DTM and GPC (0.53), DTM and $\mathrm{GZnC}(0.55)$. Earlier, the similar relationship among these traits was reported by Magallanes-López et al., (2017), Kumar et al., (2017), and Ahmad and Kumar (2017).

The significant negative correlation between yield and yield component traits and nutrient traits was observed between GPC and GYPP $(\mathrm{r}=-0.63)$ and GYPP and GZnC $(\mathrm{r}=--0.54)$ respectively, Tiwari et al., (2016) also observed similar relationship among these traits. However Dodig et al., (2012) observed significant positive correlation between several of such traits such as GYPP, DTM, PH DTH etc.

Previous studies also found same results of correlation among above mentioned traits (Garvin et al., 2006; Oury et al., 2006; Morgounov et al., 2007; McDonald et al., 2008; Badakhshan et al., 2013; Amiri et al., 2015; Peterson et al., 1986; Cakmak et al., 2004; Demirkiran, 2009; Peleg et al., 2009; Zhao et al., 2009; Chatzav et al., 2010; Wang et al., 2011). The details of remaining significant correlation among the different traits presented in Table 3 . 
Table.1 Details of the ANOVA results showing mean squares for all the 15 traits measured on 308 wheat genotypes

\begin{tabular}{|c|c|c|c|c|c|c|c|c|c|c|c|c|c|c|c|c|}
\hline \multirow{2}{*}{$\begin{array}{l}\text { Source of } \\
\text { Variations }\end{array}$} & \multirow[t]{2}{*}{ DF } & \multicolumn{15}{|c|}{ Traits } \\
\hline & & DTH & DTA & DTM & GFD & $\mathrm{PH}$ & TNPP & GNPS & GWPS & TGW & BY & GYPP & GPC & GBCC & $\mathrm{GFeC}$ & $\mathrm{GZnC}$ \\
\hline Replications & 1 & $20.33^{*}$ & $4.53 * *$ & $33.8 * *$ & $62.09 *$ & $236.65^{* *}$ & $0.93 * *$ & $12.00^{* *}$ & $0.01 * *$ & $0.07 * *$ & 180313* & $68853 *$ & $0.75 * *$ & 71.06 & $497.35^{*}$ & $78.54 *$ \\
\hline $\begin{array}{l}\text { Blocks with in } \\
\text { Replications (Adj) }\end{array}$ & 34 & $2.18 * *$ & $365.65 *$ & $250.16^{*}$ & $57.00 *$ & $671.52 *$ & $4.56^{* *}$ & $152.22 * *$ & $0.65^{*}$ & $109.44 * *$ & $132787 * *$ & $48747 *$ & $5.78 *$ & $0.95 * *$ & $58.74 * *$ & $72.85^{*}$ \\
\hline $\begin{array}{l}\text { Treatments } \\
\text { (Unadj) }\end{array}$ & 323 & 189.11 & $91.34 * *$ & $87.70 * *$ & $22.58 * *$ & $244.65^{* *}$ & $5.06^{* *}$ & $95.74 * *$ & $0.29 * *$ & $57.62 * *$ & $58891 * *$ & $12735 * *$ & $1.99 * *$ & $0.66^{* *}$ & $40.42^{* *}$ & $20.5^{* *}$ \\
\hline Intra Block Error & 289 & $1.66^{* *}$ & $54.21 * *$ & $57.62 * *$ & $15.58^{* *}$ & $198.75 * *$ & $4.67 * *$ & $56.03 * *$ & $0.17 * *$ & $38.95 * *$ & $47513 * *$ & $8464.81 * *$ & $1.13 * *$ & $0.61 * *$ & $36.14^{* *}$ & $15.36^{* *}$ \\
\hline
\end{tabular}

Table.3 Correlation coefficients among 15 micronutrients and yield related traits recorded on 308 wheat genotypes

\begin{tabular}{|c|c|c|c|c|c|c|c|c|c|c|c|c|c|c|c|}
\hline Traits & DTH & DTA & DTM & GFD & PH & TNPP & GNPS & GWPS & TGW & BY & GYPP & GPC & GBCC & GFeC & $\begin{array}{l}\text { GZn } \\
\text { C }\end{array}$ \\
\hline DTH & 1 & & & & & & & & & & & & & & \\
\hline DTA & $0.99 * *$ & 1 & & & & & & & & & & & & & \\
\hline DTM & $0.88 * *$ & $0.88 * *$ & 1 & & & & & & & & & & & & \\
\hline GFD & $-0.31 * *$ & $-0.31 * *$ & $0.16^{* *}$ & 1 & & & & & & & & & & & \\
\hline PH & $0.30 * *$ & $0.30 * *$ & $0.30 * *$ & -0.02 & 1 & & & & & & & & & & \\
\hline TNPP & $0.15 * *$ & $0.15^{* *}$ & $0.15 * *$ & -0.01 & 0.07 & 1 & & & & & & & & & \\
\hline GNPS & $-0.40 * *$ & $-0.41 * *$ & $-0.33 * *$ & $0.21 * *$ & $-0.34 * *$ & -0.07 & 1 & & & & & & & & \\
\hline GWPS & $-0.52 * *$ & $-0.53 * *$ & $-0.41 * *$ & $0.29 * *$ & $-0.35 * *$ & $-0.14 *$ & $0.83^{* *}$ & 1 & & & & & & & \\
\hline TGW & $-0.47 * *$ & $-0.48 * *$ & $-0.36 * *$ & $0.29 * *$ & $-0.23 * *$ & $-0.17 * *$ & $0.33 * *$ & $0.79 * *$ & 1 & & & & & & \\
\hline BY & $-0.14 * *$ & $-0.15 * *$ & $-0.20 * *$ & -0.09 & 0.10 & -0.04 & $0.14^{*}$ & $0.14 *$ & 0.09 & 1 & & & & & \\
\hline GYPP & $-0.70 * *$ & $-0.72 * *$ & $-0.65 * *$ & $0.18 * *$ & $-0.36 * *$ & $-0.11 *$ & $0.49 * *$ & $0.60 * *$ & $0.52 * *$ & $0.38 * *$ & 1 & & & & \\
\hline GPC & $0.59 * *$ & $0.60 * *$ & $0.53 * *$ & $-0.18 * *$ & $0.25 * *$ & 0.07 & $-0.42 * *$ & $-0.50 * *$ & $-0.40 * *$ & -0.09 & $-0.63 * *$ & 1 & & & \\
\hline GBCC & 0.06 & 0.06 & 0.05 & -0.02 & -0.06 & -0.05 & $0.15^{* *}$ & 0.04 & -0.09 & 0.03 & 0.03 & -0.06 & 1 & & \\
\hline GFeC & 0.03 & 0.05 & 0.02 & -0.06 & $0.11 *$ & 0.04 & -0.01 & -0.05 & -0.08 & -0.00 & -0.09 & $0.11 *$ & -0.03 & 1 & \\
\hline GZnC & $0.59 * *$ & $0.60 * *$ & $0.55 * *$ & $-0.15 * *$ & $0.38 * *$ & $0.16^{* *}$ & $-0.34 * *$ & $-0.39 * *$ & $-0.31 * *$ & $-0.16^{* *}$ & $-0.54 * *$ & $0.50 * *$ & 0.01 & $0.16^{* *}$ & 1 \\
\hline
\end{tabular}


Table.2 Estimates of mean, range, standard deviation (SD), coefficient of variance (CV) and heritability in broad sense $\left(\mathrm{h}^{2}\right)$ for 15 nutrition and yield related traits in 308 wheat genotypes of SWRS

\begin{tabular}{|l|l|l|l|l|l|l|}
\hline S. No. & Traits & Mean \pm SE & Range & S.D. & $\mathbf{C V ~}(\mathbf{\%})$ & $\mathbf{h}^{\mathbf{2}}(\mathbf{\%})$ \\
\hline $\mathbf{1}$ & DTH (days) & $90.53 \pm 0.57$ & $71.50-128.50$ & 9.97 & 11.01 & 99.54 \\
\hline $\mathbf{2}$ & DTA (days) & $95.80 \pm 0.55$ & $80.00-132.00$ & 9.64 & 10.00 & 99.52 \\
\hline $\mathbf{3}$ & DTM (days) & $133.22 \pm 0.53$ & $115.00-159.50$ & 9.30 & 6.90 & 99.63 \\
\hline $\mathbf{4}$ & GFD (days) & $37.43 \pm 0.26$ & $24.50-46.50$ & 4.55 & 12.10 & 96.04 \\
\hline $\mathbf{5}$ & PH (cm) & $106.10 \pm 0.92$ & $60.45-149.03$ & 16.06 & 15.10 & 99.68 \\
\hline $\mathbf{6}$ & TNPP (no.) & $8.88 \pm 0.13$ & $4.00-18.50$ & 2.22 & 25.00 & 98.19 \\
\hline $\mathbf{7}$ & GNPS (no.) & $45.18 \pm 0.51$ & $17.00-61.50$ & 8.97 & 19.80 & 97.06 \\
\hline $\mathbf{8}$ & GWPS (g) & $1.64 \pm 0.03$ & $0.48-2.74$ & 0.51 & 31.10 & 97.68 \\
\hline $\mathbf{9}$ & TGW $(\mathrm{g})$ & $35.76 \pm 0.41$ & $15.25-53.19$ & 7.16 & 20.00 & 96.70 \\
\hline $\mathbf{1 0}$ & BY $(\mathrm{g})$ & $1234.38 \pm 13.58$ & $387.50-1750.00$ & 238.34 & 19.30 & 96.57 \\
\hline $\mathbf{1 1}$ & GYPP $(\mathrm{g})$ & $358.04 \pm 5.81$ & $100.00-562.50$ & 101.95 & 28.47 & 85.62 \\
\hline $\mathbf{1 2}$ & GPC $(\mathbf{\%})$ & $13.37 \pm 0.07$ & $11.18-17.93$ & 1.24 & 9.20 & 88.96 \\
\hline $\mathbf{1 3}$ & GBCC $(\mathrm{mg} / \mathrm{kg})$ & $4.81 \pm 0.04$ & $2.65-6.90$ & 0.69 & 14.34 & 78.81 \\
\hline $\mathbf{1 4}$ & GFeC $(\mathrm{ppm})$ & $40.09 \pm 0.28$ & $29.20-59.50$ & 4.92 & 12.27 & 64.07 \\
\hline $\mathbf{1 5}$ & GZnC $(\mathrm{ppm})$ & $23.10 \pm 0.22$ & $11.70-39.05$ & 3.82 & 16.53 & 74.48 \\
\hline
\end{tabular}

Table.4 Clustering pattern of 308 wheat genotypes into 12 clusters on the basis of $\mathrm{D}^{2}$ analysis

\begin{tabular}{|c|c|c|c|}
\hline $\begin{array}{l}\text { S. } \\
\text { No. }\end{array}$ & $\begin{array}{l}\text { Cluster } \\
\text { No. }\end{array}$ & $\begin{array}{l}\text { No. of } \\
\text { genotypes }\end{array}$ & S. No. of genotypes \\
\hline 1 & I & 67 & $\begin{array}{l}1,3,4,6,7,10,12,20,21,24,29,40,42,44,47,51,52,56,57,60,78,80,81,83,94,98,101, \\
102,104,106,107,111,113,114,117,118,119,121,122,124,125,127,131,132,136, \\
137,140,144,149,155,164,169,186,195,203,206,210,240,258,280,294,295,297, \\
302,312,321 .\end{array}$ \\
\hline 2 & II & 47 & $\begin{array}{l}5,9,11,14,16,17,23,30,35,36,37,38,46,62,64,65,66,68,69,72,77,89,91,93,176, \\
177,178,200,204,215,226,230,231,242,245,249,256,289,307,308,313,317,319, \\
324,327,328,330 .\end{array}$ \\
\hline 3 & III & 19 & $8,27,31,33,39,43,50,53,63,67,73,74,84,86,108,175,276,287,293$ \\
\hline 4 & IV & 27 & $\begin{array}{l}18,45,70,85,96,112,126,139,152,160,167,179,180,227,229,233,235,246,250 \\
252,257,259,283,304,305,318,325\end{array}$ \\
\hline 5 & V & 22 & $\begin{array}{c}19,26,28,34,41,48,55,59,79,87,130,194,239,247,253,268,281,282,284,290, \\
300,316 .\end{array}$ \\
\hline 6 & VI & 14 & $25,105,138,157,174,185,209,234,266,270,272,285,301,311$. \\
\hline 7 & VII & 17 & $71,88,103,115,198,207,208,220,228,236,238,244,260,262,298,323,326$. \\
\hline 8 & VIII & 43 & $\begin{array}{l}75,109,110,116,123,128,134,135,141,142,145,146,153,162,163,166,168,170, \\
171,173,182,184,189,190,192,193,201,202,217,218,219,222,237,241,264,265 \\
273,274,275,277,292,299,320 .\end{array}$ \\
\hline 9 & IX & 20 & $\begin{array}{l}82,133,143,147,150,154,158,165,181,187,188,191,211,223,225,248,251,255 \\
286,296 .\end{array}$ \\
\hline 10 & $\mathrm{X}$ & 7 & $120,159,172,199,212,214,216$. \\
\hline 11 & XI & 13 & $129,148,156,161,205,221,224,243,261,267,278,303,309$. \\
\hline 12 & XII & 12 & $151,183,196,197,263,269,271,288,291,310,322,329$. \\
\hline
\end{tabular}


Table.5 Intra-cluster (bold) and inter-cluster $\mathrm{D}^{2}$ values among 12 clusters of wheat genotypes

\begin{tabular}{|l|l|l|l|l|l|l|l|l|l|l|l|l|}
\hline Cluster & I & II & III & IV & V & VI & VII & VIII & IX & X & XI & XII \\
\hline I & $\mathbf{1 3 8 . 0 0}$ & & & & & & & & & & \\
\hline II & $\mathbf{6 9 6 . 9 3}$ & $\mathbf{1 6 3 . 5 5}$ & & & & & & & & & \\
\hline III & 410.52 & 314.59 & $\mathbf{7 4 . 8 1}$ & & & & & & & & \\
\hline IV & 483.85 & 242.40 & 209.03 & $\mathbf{6 5 . 2 5}$ & & & & & & & \\
\hline V & 263.46 & 461.30 & 152.94 & 297.98 & $\mathbf{7 3 . 5 1}$ & & & & & & \\
\hline VI & 417.43 & 286.89 & 149.68 & 75.99 & 22.51 & $\mathbf{4 4 . 5 3}$ & & & & & \\
\hline VII & 390.99 & 335.02 & 201.14 & 97.04 & 236.72 & 64.14 & $\mathbf{4 6 . 1 7}$ & & & & \\
\hline VIII & 221.69 & 497.95 & 264.33 & 268.82 & 181.94 & 211.39 & 172.93 & $\mathbf{6 3 . 6 0}$ & & & \\
\hline IX & 343.62 & 388.74 & 223.41 & 150.53 & 221.93 & 109.87 & 54.43 & 122.76 & $\mathbf{4 1 . 7 4}$ & & \\
\hline X & 326.28 & 371.06 & 131.10 & 171.28 & 132.66 & 97.04 & 105.10 & 140.43 & 102.18 & $\mathbf{3 1 . 9 7}$ & \\
\hline XI & 365.45 & 334.61 & 135.94 & 127.63 & 174.01 & 53.72 & 71.25 & 166.25 & 89.69 & 44.47 & $\mathbf{4 0 . 7 5}$ & \\
\hline XII & 524.43 & 172.98 & 154.59 & 116.81 & 291.63 & 124.91 & 183.88 & 331.52 & 233.90 & 199.44 & 165.89 & $\mathbf{9 7 . 1 5}$ \\
\hline
\end{tabular}

Table.6 Cluster means values for 15 micronutrients and yield related traits in 308 wheat genotypes

\begin{tabular}{|c|c|c|c|c|c|c|c|c|c|c|c|c|}
\hline \multirow[t]{2}{*}{ Traits } & \multicolumn{12}{|c|}{ Clusters } \\
\hline & I & II & III & IV & V & VI & VII & VIII & IX & $\mathrm{X}$ & XI & XII \\
\hline DTH & 88.69 & 95.67 & 102.97 & 86.02 & 98.21 & 86.29 & 86.91 & 87.05 & 84.78 & 90.43 & 85.89 & 94.29 \\
\hline DTA & 93.81 & 100.93 & 108.21 & 91.41 & 103.59 & 91.82 & 92.18 & 92.20 & 90.35 & 95.43 & 91.12 & 99.71 \\
\hline DTM & 130.36 & 137.88 & 144.87 & 129.46 & 139.55 & 129.54 & 131.47 & 129.91 & 129.85 & 131.07 & 131.00 & 137.38 \\
\hline GFD & 36.55 & 36.96 & 36.66 & 38.06 & 35.96 & 37.71 & 39.29 & 37.71 & 39.50 & 35.64 & 39.89 & 37.67 \\
\hline PH & 107.41 & 105.81 & 119.18 & 98.87 & 119.32 & 103.73 & 99.46 & 100.24 & 102.74 & 110.95 & 106.31 & 106.86 \\
\hline TNPP & 8.62 & 8.98 & 8.76 & 8.43 & 10.16 & 8.50 & 8.44 & 9.00 & 8.50 & 7.79 & 9.35 & 10.17 \\
\hline GNPS & 46.41 & 39.59 & 38.84 & 47.17 & 41.67 & 48.01 & 51.87 & 47.66 & 48.68 & 43.26 & 45.50 & 45.47 \\
\hline GWPS & 1.71 & 1.33 & 1.17 & 1.73 & 1.29 & 1.93 & 2.05 & 1.85 & 1.87 & 1.49 & 1.67 & 1.64 \\
\hline TGW & 36.49 & 32.70 & 29.73 & 36.54 & 30.20 & 40.09 & 39.51 & 38.97 & 38.17 & 34.79 & 36.77 & 35.15 \\
\hline BY & 1554.48 & 874.20 & 1186.84 & 1070.83 & 1335.23 & 1139.29 & 1163.97 & 1335.76 & 1213.13 & 1233.93 & 1192.31 & 1044.79 \\
\hline GY & 405.22 & 254.52 & 225.00 & 394.91 & 260.80 & 362.50 & 421.32 & 440.41 & 443.75 & 344.64 & 356.73 & 282.29 \\
\hline GPC & 13.39 & 14.11 & 14.66 & 12.77 & 13.94 & 12.89 & 12.64 & 12.92 & 12.82 & 13.11 & 12.58 & 13.63 \\
\hline GBCC & 4.89 & 4.79 & 4.80 & 4.93 & 4.77 & 4.99 & 4.82 & 4.82 & 4.77 & 4.64 & 4.31 & 4.78 \\
\hline GFeC & 40.05 & 40.54 & 41.00 & 40.53 & 41.03 & 40.16 & 38.03 & 39.87 & 40.49 & 40.40 & 37.52 & 39.94 \\
\hline GZnC & 22.70 & 24.85 & 27.13 & 22.02 & 24.61 & 22.76 & 22.70 & 21.40 & 20.59 & 22.00 & 21.48 & 25.53 \\
\hline
\end{tabular}

Table.7 Divergent and desirable genotypes for specific traits, which are likely to produce most promising crosses

\begin{tabular}{|l|l|l|l|l|} 
S. No & Trait & $\begin{array}{l}\text { Clusters with higher } \\
\text { trait value and higher } \\
\text { intra-cluster distance }\end{array}$ & $\begin{array}{l}\text { Genotypes } \\
\text { selected }\end{array}$ & $\begin{array}{l}\text { Desirable } \\
\text { cross combinations }\end{array}$ \\
\hline $\mathbf{1}$ & GFeC & V \& V & $282($ Chih95.4.3) & V $\times$ V \\
\hline $\mathbf{2}$ & GZnC & III\& I & $29($ W-63) & I $\times$ III \\
\hline $\mathbf{3}$ & GBCC & VI \& XII & $291($ Castilla-AG & VI $\times$ XII \\
\hline $\mathbf{4}$ & GPC & III\& II & $72($ Citr-8327) & I $\times$ II \\
\hline
\end{tabular}


Table.8 List of most important common genotypes with higher trait values of different traits

\begin{tabular}{|l|l|l|}
\hline \multirow{2}{*}{ Genotypes } & \multicolumn{2}{|c|}{ Traits } \\
\hline Castilla-AG & 17.45 & GBCC $(\mathrm{kg} / \mathrm{mg})$ \\
\hline Genotypes & GPC $(\%)$ & 6.9 \\
\hline W-39 & 17.24 & GZnC $(\mathrm{ppm})$ \\
\hline W-63 & 16.97 & 32.25 \\
\hline W-37 & 16.5 & 39.05 \\
\hline Genotypes & GFeC (ppm) & 32.7 \\
\hline Gray JD-1102 & 53.6 & GBCC $(\mathrm{kg} / \mathrm{mg})$ \\
\hline OAX93.10.1 & 50.9 & 6.55 \\
\hline Genotypes & GZnC (ppm) & GFeC $(\mathrm{ppm})$ \\
\hline Qitai Chun 4 ST-119 & 37.05 & 52.5 \\
\hline Turpan Shan Yueh HCM & 31.8 & 54.45 \\
\hline Genotypes & GZnC (ppm) & GBCC $(\mathrm{kg} / \mathrm{mg})$ \\
\hline Citr-15308 & 36.2 & 6.35 \\
\hline Jupateco F-73 & 33.85 & 6.35 \\
\hline
\end{tabular}

For bio fortification purposes, it is important to break this negative relationship and to breed varieties that contain high levels of trace elements without any yield penalty (Peterson et al., 1986; Cakmak et al., 2004; Morgounov et al., 2007; Demirkiran, 2009; Peleg et al., 2009; Zhao et al., 2009; Chatzav et al., 2010; Wang et al., 2011), A single $G p c-B 1$ (Grain protein content-B1) locus affects the concentration of GPC, GFeC and GZnC in wheat (Distelfeld et al., 2007). The positive correlations between $\mathrm{GFeC}$, GZnC and GPC would be useful information for wheat breeders and further studies could include a larger set of modern varieties with high GPC and micronutrients in the wheat breeding program.

\section{Genetic divergence}

The germplasm of a crop is a reservoir of genetic diversity in that crop. To initiate any crop improvement program, identification of desirable and genetically divergent parents is a pre-requisite. Genetic divergence among the accessions of a germplasm can be estimated from variation present among the accessions of the germplasm in respect of the set of important traits. In the present study using the phenotypic values of 15 quantitative traits, 308 genotypes were grouped into 12 clusters (Table 4). The intra and inter cluster values of these 12 clusters are presented in Table 5. The intra cluster values ranged from 31.97 (cluster $\mathrm{X})$ to 163.55 (cluster II), whereas the intercluster values from 44.47 (cluster $\mathrm{X}$ ) to 696.93 (cluster II). While the relative magnitude of intra cluster value indicates the variation among the genotypes present within a single cluster, the relative magnitude of inter cluster values indicates the level of genetic dissimilarity or divergence between the genotypes of paired combinations of the clusters.

Based on the higher magnitude of intercluster distance, the clusters I and II (intercluster distance 696.93), followed by the clusters XII and I (inter cluster distance 524.43), and cluster II and VIII (in the cluster distance 497.95) were identified as the most divergent clusters (Table 5). 
The divergent and desirable genotypes from germplasm used in present study were identified as those which fall in divergent clusters and have the higher desirable mean values than other genotypes, falling in the same clusters. The cluster-wise mean values of the traits under study are presented in Table 6. Based on the aforementioned criteria, the divergent and desirable genotypes were identified for each of the important traits, which are presented in Table 6.

These genotypes are likely to be most promising in hybridization program aimed at producing good heterotic cross or selecting of most desirable plants in segregation populations of such divergent and promising crosses (Table 7). In order to determine as to whether these genotypes should be involved in producing most heterotic crosses or in a hybridization program followed by the selection of most promising plants in respect to specific trait in the segregating generations, they should also be subjected to testing of general combining ability (GCA) and specific combining ability (SCA), respectively.

\section{Diverse and desirable wheat genotypes for micronutrient and protein contents}

Our study showed significant genotypic variation among 308 wheat genotypes with respect to the concentration of protein and micronutrient such as GBCC, GFeC, GZnC, which were also documented earlier by several researchers (Welch et al., 2005; OrtizMonasterio et al., 2007; Zhao et al., 2009). This genetic diversity which might be due to different genetic resources involved or due to greater uptake and allocation of the micronutrients to the grain. It can be utilized to enhance iron and zinc composition through conventional and modern breeding approaches (Rawat et al., 2013). So, it could provide an opportunity to select or generate genotypes with higher GPC, GBCC, GFeC and $\mathrm{GZnC}$ in their edible parts. On the basis of genotypic variation among 308 wheat genotypes, we selected 10 extreme genotypes for micronutrients and GPC. Further, 10 common genotypes with higher traits value were selected for micronutrients and GPC, these results suggested that common genotypes with higher value of these traits may be useful for development of bi-parental mapping population for multiple traits simultaneously, but verification of these genotypes must be required in multiple environments before use in breeding programme (Table 8 ).

\section{Author contribution statement}

Conceived and designed the experiments: PKS. Collection of data on traits: IAJK VKM. Analysis of data: IA JK PKS. Wrote the paper: JK PKS IA NG.

\section{Acknowledgments}

All authors acknowledge the Head, Genetics and Plant Breeding, CCS University, Meerut provided the facilities and the DBT-BIF facilities also gratefully acknowledged. JK acknowledge the ICMR for the fellowship grant during this research.

\section{References}

Ahmad, A. and Kumar, J. 2017. Estimation of character association and path coefficient analysis in among different yield related component wheat genotypes (Triticum aestivum L.). Progressive Research 12 (3): 336-338.

Allard, R.W. 1960. Principles of Plant Breeding. John Wiley and Sons. Inc. New York.

Amiri, R., Bahraminejada, S., Sasanib, S., Jalali-Honarmanda, S., and Fakhric, R. (2015). Bread wheat genetic variation for grain's protein, iron and zinc 
concentrations as uptake by their genetic ability. Europ. J. Agronomy, 67: 20-26.

Asif, M., Mujahid, M.Y., Kisana, N.S., Mustafa, S.Z. and Ahmad, I. 2004. Heritability, genetic variability and path coefficient of some traits in spring wheat. Sarhad Journal of Agriculture, 20: 87-91.

Badakhshan, H., Moradi, N., Mohammadzadeh, H. and Zakeri, M.R. 2013.Genetic variability analysis of grains $\mathrm{Fe}, \mathrm{Zn}$ and Beta-carotene concentration of prevalent wheat varieties in Iran. Intl. J. Agri. Crop Sci., 6(2): 57-62.

Bergale, S., Billore, M., Holkar, A.S., Ruwali, K.N. and Prasad, S.V.S. 2001. Genetic variability, diversity and association of quantitative traits with grain yield in bread wheat (Triticum aestivum L.). Madras Journal of Agriculture, 88: 457461.

Bityutskii, N., Yakkonen, K. and Loskutov, I. 2017. Content of iron, zinc and manganese in grains of Triticum aestivum, Secale cereale, Hordeum vulgare and Avena sativa cultivars registered in Russia. Genetic Resources and Crop Evolution, 64(8): 1955-1961.

Cakmak, I., Tourn, A., Millet, E., Feldman, M., Fahima, T., Korol, A., Nevo, E., Braun, H.J. and Ozkan, H. 2004. Triticum dicoccoides: an important genetic resource for increasing zinc and iron concentration in modern cultivated wheat. Soil Sci Plant Nutr., 50 (7): 1047-1054.

Cakmak. 2008. Enrichment of cereal grains with zinc: agronomic or genetic biofortification. Plant and Soil, 302 (12): 1-17.

Chatzav, M., Peleg, Z., Ozturk, L., Yazici, A., Fahima, T., Cakmak, I. and Saranga, Y. 2010. Genetic diversity of grain nutrients in wild emmer wheat: potential for wheat improvement. Ann. Bot., 105(7): 1211-1220.

Colasuonno, P., Lozito, M. L., Marcotuli, I., Nigro, D., Giancaspro, A., Mangini, G. et al., (2017). The carotenoid biosynthetic and catabolic genes in wheat and their association with yellow pigments. BMC Genomics, 18 (1):122.

Demirkiran, A.R. 2009. Determination of Fe, $\mathrm{Cu}$ and $\mathrm{Zn}$ contents of wheat and corn grains from different growing site. J Anim Vet Adv., 8(8): 1563-1567.

Distelfeld, A., Cakmak, I., Peleg, Z., Ozturk, L., Yazici, A.M., Budak, H., Saranga, Y. and Fahima, T. 2007. Multiple QTLeffects of wheat Gpc-B1 locus on grain protein and micronutrient concentrations. Physiologia Plantarum, 129(3): 635-643.

Dodig, D., Zoric, M., Kobiljski, B., Savic, J., Kandic, V., Quarrie, S. and Barnes, J. 2012. Genetic and association mapping study of wheat agronomic traits under contrasting water regimes. International Journal of Molecular Sciences, 13(5): 6167-6188.

Dwivedi, A.N., Pawar, I.S., Shashi, M. and Madan, S. (2002). Studies on variability parameters and character association among yield and quality attributing traits in wheat. Haryana Agric. Univ. J. Res., 32 (2): 77-80.

Garvin, D.F., Welch, R.M. and Finley, J.W. 2006. Historical shifts in the seed mineral micronutrient concentration of US hard red winter wheat germplasm. J. Sci. Food Agric., 86(13): 2213-2220.

Geisler-Lee, J. and Gallie, D.R. 2005. Aleurone cell identity is suppressed following connation in maize kernels. Plant Physiol., 139(1): 204-212

Gillies, S.A., Futardo, A. and Henry, R.J. 2012. Gene expression in the developing aleurone and starchy endosperm of wheat. Plant Biotech J., 10(6): 668-679. 
Kumar, A., Kumar, J., and Kumar A. 2017. To study the correlation and pathcoefficient analysis of bread wheat (Triticum aestivum L.) genotypes. Progressive Research 12 (3): 320-322.

Liu, K. 2011. Comparison of lipid content and fatty acid composition and their distribution within seeds of 5 small grain species. J. Food Sci., 76 (2): 334342 .

Magallanes-López, A.M., HernandezEspinosa, N., Velu, G., PosadasRomano, G.et al., 2017. Variability in iron, zinc and phytic acid content in a worldwide collection of commercial durum wheat cultivars and the effect of reduced irrigation on these traits. Food Chemistry, 237: 499-505.

Mahalanobis, P.C. 1936. The generalized distance in statistics. Pro. India Nat. Inst. Sci., 2: 49-55.

McDonald, G.K., Genc, Y. and Graham, R.D. 2008. A simple method to evaluate genetic variation in grain zinc concentration by correcting for differences in grain yield. Plant and Soil, 306 (1-2): 49-55.

Morgounov, A., Gomez-Becerra, H.F., Abugalieva, A., Dzhunusova, M. et al., 2007. Iron and zinc grain diversity in common wheat grown in central Asia. Euphytica, 155 (1-2): 193-203.

Nguni, D., Geleta, M., Hofvander, P., Fatih, M., Bryngelsson, T. 2012. Comparative genetic diversity and nutritional quality variation among some important southern African sorghum accessions (Sorghum bicolor (L.) Moench). Aust J Crop Sci., 6(1): 56-64.

Ortiz-Monasterio, I., Palacios-Rojas, N., Meng, E., Pixley, K., Trethowan, R. and Pena, R.J. 2007. Enhancing the mineral and vitamin content of wheat and maize through plant breeding. J Cereal Sci., 46(3): 293-307.
Oury, F.X., Leenhardt, F., Remesy, C., Chanliaud, E., Duperrier, B., Balfourier, F. and Charmet, G. 2006. Genetic variability and stability of grain magnesium, zinc and iron concentrations in bread wheat. Eur J Agron., 25(2): 177-185.

Paltridge, N.G., Palmer, L.J., Milham, P.J. et al., 2012. Energy-dispersive X-ray fluorescence analysis of zinc and iron concentration in rice and pearl millet grain. Plant Soil, 361(1-2): 251-260.

Peleg, Z., Cakmak, I., Ozturk, L., Yazici, A., Jun, Y., Budak, H., Korol, A.B., Fahima, T. and Saranga, Y. 2009. Quantitative trait loci conferring grain mineral nutrient concentrations in durum wheat $x$ wild emmer wheat RIL population. Theor. Appl. Genet., 119 (2): 353-369.

Peterson, C.J., Johnson, V.A., Mattern, P.J. 1986. Influence of cultivar and environment on mineral and protein concentrations of wheat flour, bran and grain. Cereal Chem, 63(3): 183-186.

Rawat, N., Neelam, K., Tiwari, V.K. and Dhaliwal, H.S. 2013. Biofortification of cereals to overcome hidden hunger. Plant Breed, 132(5): 437-445.

Regvar, M., Eichert, D., Kaulich, B., Gianoncelli, A., Pongrac, P., VogelMikus, K. and Kreft, I. 2011. New insights into globoids of protein storage vacuoles in wheat aleurone using synchrotron soft X-ray microscopy. J. Exp. Bot., 62(11): 3929-3939.

Tiwari, C., Wallwork, H., Arun, B. et al., 2016. Molecular mapping of quantitative trait loci for zinc, iron and protein content in the grains of hexaploid wheat. Euphytica, 207(3): 563-570.

Tripathi, S.N., Marker, S., Pandey, P., Jaiswal, K.K. and Tiwari, D.K. 2011. Relationship between some morphological and physiological traits 
with grain yield in bread wheat (Triticum aestivum L.em.Thell.). Trends Appl Sci Res., 6(9): 1037-1045.

Velu, G., Guzman, C., Mondal, S. et al., 2016. Effect of drought and elevated temperature on grain zinc and iron concentrations in CIMMYT spring wheat. J Cereal Sci., 69:182-186.

Wang, S., Yin, L., Tanaka, H., Tanaka, K. and Tsujimoto, H. 2011. Wheat-Aegilops chromosome addition lines showing high iron and zinc contents in grains. Breeding Sci., 61(2): 189-195.

Ward Jr, J.H. 1963. Hierarchical grouping to optimize an objective function. J. Am. Stat. Assoc., 58(301): 236-244.

Welch, R.M. and Graham, R.D. 2004. Breeding for micronutrients in staple food crops from a human nutrition perspective. J. Exp. Bot., 55(396): 353364.

Welch, R.M., House, W.A., Ortiz-Monasterio, I. and Cheng, Z. 2005. Potential for improving bioavailable zinc in wheat grain (Triticum species) through plant breeding. Journal of Agricultural and Food Chemistry, 53(6): 2176-2180.

White, P.J. and Broadley, M.R. 2009. Biofortification of crops with seven mineral elements often lacking in human diets -iron, zinc, copper, calcium, magnesium, selenium and iodine. New Phytol., 182(1): 49-84.

World Health Organization, 2009. Global Prevalence of Vitamin A Deficiency in Populations at Risk 1995-2005: WHO Global Database on Vitamin A Deficiency.

Zhao, F.J., Su, Y.H., Dunhama, S.J., Rakszegi, M., Bedo, Z. et al., 2009. Variation in mineral micronutrient concentrations in grain of wheat lines of diverse origin. J Cereal Sci., 49(2): 290295.

\section{How to cite this article:}

Ishan Ahmed, Jitendra Kumar, Neha Goel, Vinod Kumar Mishra and Pradeep Kumar Sharma. 2018. Characterization of Variability, Genetic Divergence and Character Association in Wheat Germplasm of SWRS in Respect of Nutrition and Yield Traits. Int.J.Curr.Microbiol.App.Sci. 7(05): 303-314. doi: https://doi.org/10.20546/ijcmas.2018.705.039 